\title{
Model latihan fisik jalan kaki dengan pemberian jus galoba terhadap komposisi lemak tubuh dan status antioksidan pada wanita usia $>55$ tahun
}

\author{
Physical training model of footway with galoba juice to body fat composition \\ and antioxidant status in women age $>55$ years old
}

\section{Abdul Rivai Saleh Dunggio ${ }^{*}$}

\author{
${ }^{1}$ Politeknik Kesehatan Kemenkes \\ Maluku, Maluku, Indonesia. \\ E-mail: rivaidunggio2016@gmail.com
}

\section{*Korespondensi:}

Politeknik Kesehatan Kemenkes Maluku, Jl. Laksdya Leo Wattimena, Negeri Lama Ambon, Maluku, Indonesia. E-mail: rivaidunggio2016@gmail.com

\section{Riwayat Artikel:}

Diterima tanggal 3 Februari 2020; Direvisi tanggal 13 Juli 2020; Disetujui tanggal 10 Oktober 2020; Dipublikasi tanggal 26 Mei 2021.

\section{Penerbit:}

Politeknik Kesehatan Aceh Kementerian Kesehatan RI

\section{(c) The Author(s). 2021 Open Access}



Artikel ini telah dilakukan distribusi berdasarkan atas ketentuan Lisensi Internasional Creative Commons Attribution 4.0

\begin{abstract}
Walking can affect the muscles to stretch which can improve physical fitness for prevention in elderly women. Galoba contains flavonoids that have antioxidative properties and play a role in preventing damage to cells and their cellular components by reactive free radicals. The aim of the study was to determine the effectiveness of the physical exercise model walking by giving galoba juice on body fat composition and antioxidant status in women aged $>$ 55 years. This study was a true experiment with a pre-posttest with a control group. Consecutive admission sampling technique, as many as 20 people. Data collection was carried out by observing mothers who did walking sports by giving galoba juice for 14 consecutive days with a walking time of 25 minutes. Statistical was using the Independent t-test. The results obtained that the average value of body fat composition after walking was $38,1 \%<$ after walking with galoba juice $42,2 \%, p=0,372(p>0,05)$. The average value of total antioxidants after walking was $1,58 \mu \mathrm{g} / \mathrm{mL}<$ after walking with galoba juice was $1,59 \mu \mathrm{g} / \mathrm{mL}, \mathrm{p}=0,527(\mathrm{p}>0,05)$. The conclusion is that there is no effect of walking physical exercise on body fat composition and there is no effect of the physical exercise model walking with the provision of galoba juice on total antioxidant levels.
\end{abstract}

Keywords: Body fat composition, total antioxidant, walking

\section{Abstrak}

Berjalan kaki dapat mempengaruhi otot untuk meregang yang dapat meningkatkan kebugaran fisik untuk pencegahan pada wanita lanjut usia. Galoba mengandung Flavonoid memiliki sifat antioksidatifserta berperan dalam mencegah kerusakan sel dan komponen selularnya oleh radikal bebas reaktif. Tujuan penelitian untuk mengetahui efektifitas model latihan fisik jalan kaki dengan pemberian jus galoba terhadap komposisi lemak tubuh dan status antioksidan pada wanita usia $>55$ tahun. Penelitian eksperimen murni dengan pre-post test with control group. Tehnik pengambilan sampel secara consecutive admission, sebanyak 20 orang. Pengumpulan data dilakukan dengan cara observasi terhadap ibu-ibu yang Melakukan olahraga jalan kaki dengan pemberian jus galoba selama 14 hari berturut-turut dengan waktu jalan kaki selama 25 menit. Statistik menggunakan Independent t-test. Hasil didapatkan nilai rata-rata komposisi lemak tubuh sesudah jalan kaki 38,1\% < sesudah jalan kaki dengan pemberian jus galoba $42,2 \%$ dengan nilai $p=0,372(p>0,05)$. Nilai rata-rata total anti oksidan sesudah jalan kaki $1,58 \mu \mathrm{g} / \mathrm{mL}<$ sesudah jalan kaki dengan pemberian jus galoba $1,59 \mu \mathrm{g} / \mathrm{mL}$, nilai $\mathrm{p}=0,527(\mathrm{p}>0,05)$. Kesimpulan tidak ada pengaruh latihan fisik jalan kaki terhadap komposisi lemak tubuh dan tidak ada pengaruh model latihan fisik jalan kaki dengan pemberian jus galoba terhadap kadar total antioksidan.

Kata Kunci: Jalan kaki, komposisi lemak tubuh, total atioksidan 


\section{Pendahuluan}

Galoba adalah salah potensi flora endemik yang ada di Provinsi Maluku yang tersebar di Pulau Seram Bagian Barat dan Daerah Kecamatan Leihitu. Distribusi tanaman ini di Ambon dapat ditemukan di beberapa tempat seperti dataran tinggi dan daerah pantai. Galoba adalah spesies milik keluarga Amomum genera Zingiberaceae. Tanaman ini juga digunakan sebagai tanaman obat untuk penyakit pinggang dan ginjal. Tanaman ini merupakan jenis buah-buahan (Salamena et al., 2018).

Meningkatkan kebiasaan mengkonsumsi sayur dan buah-buahan, melakukan aktifitas fisik dan memeriksakan kesehatan secara rutin adalah fokus Gerakan Masyarakat Hidup Sehat (GERMAS). Sebagai Gerakan Nasional yang diprakarsai oleh Presiden RI yang mengedepankan upaya promotif dan preventif dalam memasyarakatkan paradigma sehat (Kemenkes RI, 2017). Lansia hendaknya selalu berolahraga yang cukup sesuai dengan kemampuan dan usianya. Olahraga jalan kaki diharapkan menjadi salah satu pilihan bagi lansia guna meningkatkan kebugaran jasmaninya karena memiliki resiko cedera rendah sekaligus jenis olahraga yang murah meriah dan menyenangkan (Junaidi, 2011). Olahraga bagi lansia merupakan sesuatu yang sangat pendng, karena olahraga dapat mendukung dalam melakukan aktivitas seharihari. Umumnya para lansia perlu meluangkan waktu atau menjadwalkan latihan untuk melakukan olahraga secara teratur (Suryanto, 2010).

Aktifitas fisik yang konsisten berperan penting dalam peningkatan perlindungan tubuh terhadap efek bahaya proses oksidasi (Polidori et al., 2000). Hasil penelitian membuktikan bahwa latihan aerobik dapat meningkatkan sistem pertahanan antioksidan di darah dan mengurangi tingkat stres oksidatif (Karolkiewics et al., 2009). Perubahan ini mungkin memanifestasikan bahwa tubuh beradaptasi terhadap stres oksidatif berulang yang disebabkan oleh olahraga, yang mengaktifkan produksi oksigen reaktif sedang spesies (ROS) dan spesies nitrogen reaktif (RNS) pada otot rangka yang berkontraksi dan dapat menstimulasi peningkatan antioksidan adaptif serta peningkatan proses perbaikan asam deoksiribonukleat atau DNA (Nikolaidis et al., 2007).
Meski telah di upayakan untuk melakukan kegiatan GERMAS, namun pada kenyataannya masyarakat Kecamatan Leihitu Kabupaten Maluku Tengah, tidak terbiasa melakukan kegiatan aerobic ataupun senam rutin. Sehingga aktifitas fisik jalan yang terukur di kalangan penduduk menjadi pilihan bentuk aktifitas fisik yang menjadi hal yang bisa didokumentasikan dalam literature. Hasil penelitian Bartlett et al. (2018) menunjukkan bahwa pelatihan berjalan dapat meningkatkan kebugaran fisik untuk pencegahan pada wanita lanjut usia yang terikat rumah. Hal ini akan menjadi lebih menarik jika di kombinasikan dengan upaya untuk mengkonsumsi buah atau pangan lokal galoba, karena galoba mengandung flavonoid dimana flavonoid merupakan senyawa fenol dan termasuk salah satumetabolit sekunder pada tumbuhan yang berfungsi sebagai antioksidan (Redha, 2010).

Antioksidan dapat menjadi strategi yang efektif untuk memperbaiki disfungsi endotel pada uremia dan target potensial untuk mengurangi risiko kardiovaskular pada populasi ini (Vera et al., 2018). Peradangan sel endotel dan biomarker yang bersirkulasi dari peradangan dan kapasitas antioksidan dikaitkan dengan kinerja latihan dan mikro sirkulasi otot betis yang iskemik selama latihan. Implikasi klinisnya adalah bahwa intervensi yang dirancang untuk mengurangi peradangan sel endotel dan biomarker inflamasi yang bersirkulasi, seperti terapi antioksidan, dapat meningkatkan kinerja olahraga pasien bergejala dengan penyakit arteri perifer (Gardner et al., 2015). Karena itu kuncinya tujuan dari penelitian ini adalah untuk menentukan efektifitas dari latihan fisik jalan kaki dengan pemberian jus galoba secara rutin selama 2 minggu (14 hari) dengan fokus pada indikator komposisi tubuh dan konsentrasi antioksidan dalam darah pada wanita usia $>55$ tahun.

\section{Metode}

Jenis penelitian ini adalah eksperimen sungguhan dengan jenis rancangan dengan rancangan pre-posttest with control group. Populasi penelitian ini adalah ibu-ibu yang berusia diatas 55 tahun, dan tehnik pengambilan sampel secara consecutive admission dan memenuhi kriteria sebanyak 20 orang yang 
dibagi dalam 2 kelompok. Penelitian ini dilakukan selama 14 hari berturut-turut di Wilayah Kerja Puskesmas Hitu Kabupaten Maluku Tengah.

Prosedur penelitian dilakukan melalui 10 orang diberi perlakukan jalan kaki ditambah minum jus galoba (kelompok intervensi), dan 10 orang lain (kelompok kontrol) diberi perlakukan jalan kaki saja.

Pengumpulan data dilakukan dengan cara observasi yaitu melakukan pengamatan selama pelaksanaan jalan kaki dan konsumsi jus galoba. Pengukuran total antioksidan dilakukan dengan menggunakan teknik laboratorium, sedangkan komposisi lemak tubuh dilakukan sebelum dan sesudah perlakukan selama 14 hari. Model penguumpulan data komposisi lemak tubuh menggunakan metode antropometri baik pada kelompok intervensi maupun kelompok kontrol.

Pengolahan data dalam penelitian dilakukan secara komputerisasi mulai dari editing, koding, tablutai dan pembersihan data. Data dalam studi ini telah berdistribusi normal berdasarkam hasil uji Kolmogorov Smirnov ( $p>0,05)$. Selanjutnya untuk menjawab tujuan penelitian, uji statistk yang digunakan yaitu Independent $t$-test. Pengambilan keputusan dengan membandingkan nilai $\mathrm{P}(\mathrm{p}$ value) dengan nilai alpa pada tingkat kemaknaan 95\%. Penelitian ini mendapat persetujuan layak etik dari Komisi Etik Penelitian Kesehatan Poltekkes Kemenkes Maluku No. LB. 02.02/6.2/2946/2019.

\section{Hasil dan Pembahasan}

\section{Pengaruh Pemberian Jus Galoba terhadap Komposisi Lemak Tubuh}

Komposisi lemak tubuh pada ibu-ibu yang melakukan latihan fisik jalan kaki baik pada kelompok intervensi (diberikan jus galoba selama 14 hari secara rutin), dan kelompok kontrol (tanpa perlakuan) disajikan pada tabel 1 berikut ini.

Tabel 1. Perubahan komposisi lemak tubuh antara yang diberikan jus galoba dengan kelompok kontrol

\begin{tabular}{|c|c|c|c|c|c|}
\hline \multicolumn{2}{|c|}{ Kelompok Perlakuan } & \multirow{2}{*}{$\frac{\text { Rerata } \pm \text { SD }}{38,3 \pm 3,559}$} & \multirow{2}{*}{$\frac{\Delta \text { Rerata } \pm \text { SD }}{0,2 \pm 0,950}$} & \multirow{2}{*}{$\begin{array}{c}95 \% \text { CI } \\
\text { (Lower - Upper) } \\
0,46-0,89\end{array}$} & \multirow{2}{*}{$\begin{array}{r}\text { Nilai p } \\
0,482\end{array}$} \\
\hline Kontrol & Sebelum & & & & \\
\hline & Setelah & $38,1 \pm 7,321$ & & & \\
\hline Intervensi & $\begin{array}{l}\text { Sebelum } \\
\text { Setelah }\end{array}$ & $\begin{array}{l}42,6 \pm 5,985 \\
42,2+5,893\end{array}$ & $0,3 \pm 0,092$ & $0,41-0,52$ & 0,184 \\
\hline
\end{tabular}

Berdasarkan hasil penelitian (tabel 1), diketahui bahwa baik pada kelompok control maupun kelompok intervensi (diberikan jus galoba) tidak menunjukkan perubahan komposisi tubuh selama 14 hari dilakukan intervensi $(p>0,05)$ pada wanita usia $>55$ tahun. Menurut Rizka \& Agus (2018) pada dasarnya Latihan Fisik yang dilakukan secara berkelanjutan dalam jangka waktu yang panjang dapat melatih kebugaran jasmani seseorang, begitu juga dengan jalan kaki. Selain melatih kebugaran jasmani, oksigen yang dihirup dan diedarkan saat berjalan kaki akan memperlancar sirkulasi darah sehingga tubuh menjadi lebih cepat lelah, tubuh dapat lebih cepat kembali kekondisi normal dan dapat mengurangi stres atau depresi.

Penelitian(Murbawani, 2017) bahwa hasil pengukuran diperoleh persen lemak tubuh terendah 7,5\% dengan hasil pengukuran aktivitas fisik yang rendah sebesar 60\%, artinya bahwa makin tinggi aktivitas yang dilakukan, maka makin menurukan komposisi lemak tubuh, sebaliknya makin rendah aktivitas yang dilakukan maka makin menaikkan komposisi lemak tubuh.

Mengenai komposisi lemak wanita usia $>55$ tahun tidak dipengaruhi oleh jalan kaki, hal ini sejalan dengan penelitian (Hafid et al., 2019), pada remaja di SMA Karuna Dipa Palu menunjukkan hasil bahwa tidak ada hubungan antara latihan fisik termasuk jalan kaki dengan komposisi lemak tubuh. Komposisi lemak tubuh tidak mengalami penurunan dikarenakan juga karena ibu-ibu yang mengikuti latihan ini tidak secara rutin dan juga tidak bisa dikendalikan pola makan seharihari. Hal ini perkuat dengan penyataan Mabele et al. (2019) bahwa 59,2\% populasi wanita memiliki tingkat latihan fisik yang rendah dan kondisi tersebut tentunya sangat berdampak terhadap komposisi tubuh mereka. 
Pengaruh Jalan Kaki dan Pemberian Jus Galoba terhadap Total Antioksidan

Hasil penelitian (tabel 2), diketahui bahwa pada wanita yang mendapat intervensi jalan kaki terjadi peningkatan total antioksidan sebesar 0,13 dengan deviasi sebesar 0,053 . Begitu juga dengan pemberian jus galoba, juga terjadi peningkatan total antioksidan sebesar 0,19 dan deviasi sebesar 0,103. Hasil uji statistik pada kedua kelompok perlakuan diperoleh nilai $\mathrm{p}<$ 0,05 . Hal ini menunjukkan bahwa terdapat pengaruh signifikan jalan kaki dan pemberian jus galoba dalam meningkatkan total antioksidan pada wanita usia diatas 55 tahun.

Tabel 2. Perubahan total antioksidan antara yang intervensi jalan kaki dengan pemberian jus galoba

\begin{tabular}{llcccc}
\hline Kelompok Perlakuan & & Rerata \pm SD & $\Delta$ Rerata \pm SD & $\begin{array}{c}95 \% \text { CI } \\
\text { (Lower - Upper) }\end{array}$ & Nilai p \\
\hline Jalan Kaki & Sebelum & $1,45 \pm 0,102$ & $0,13 \pm 0,054$ & $0,01-0,25$ & 0,037 \\
Pemberian Jus Galoba & $\begin{array}{l}\text { Setelah } \\
\text { Sebelum }\end{array}$ & $\begin{array}{l}1,58 \pm 0,145 \\
1,41 \pm 0,134\end{array}$ & $0,19 \pm 0,103$ & $0,11-0,26$ & 0,001 \\
& Setelah & $1,59 \pm 0,089$ & & & \\
\hline
\end{tabular}

Latihan fisik yang dilaksanakan secara teratur terbukti efektif mencegah berbagai penyakit kronik, baik secara primer maupun sekunder. Latihan fisik aerobik meningkatan ambilan oksigen tubuh secara bermakna, terutama terjadi pada mitokondria jaringan otot rangka yang aktif terlibat dalam kegiatan latihan. Pada latihan kardiorespirasi, terjadi peningkatan ambilan oksigen seluruh tubuh hingga 10-15 kali dengan peningkatan aliran oksigen ke sel otot yang aktif hingga lebih dari 100 kali lipat. Proses yang melibatkan seluruh tubuh ini dapat mengakibatkan stres oksidatif. Pada latihan yang berat, terjadi oksidasi glutathione, penglepasan enzim sitosol dan tanda kerusakan sel lainnya, yang diduga melibatkan xanthine oxidase dalam menghasilkan superoksida (Sudarsono, 2015). Dalam waktu yang relatif singkat, nordic walking dengan tingkat intensitas yang disesuaikan berfokus pada dominasi metabolisme lemak, penurunan lemak tubuh, dan peningkatan sistem pertahanan antioksidan darah bagi wanita yang sebelumnya tidak banyak bergerak (Cebula et al., 2017).

Rata-rata total antioksida antara sebelum dan sesudah mengikuti aktivitas fisik jalan kaki dengan minum jus galoba, dan nilai selisih antara rata-rata sebelum dan sesudah mengikuti aktivitas fisik jalan kaki adalah 0,19 hal ini bernilai positif artinya ada kecendurungan peningkatan total antioksidan tubuh sesudah mengikuti aktivitas fisik jalan kaki dan minum jus galoba.

Hasil penelitian Zuraida et al. (2017) mengatakan bahwa salah satu jenis tumbuhan yang mengandung flavonoid adalah galoba.
Sedangkan menurut Redha (2010) bahwa flavonoid memiliki efek biologis tertentu yang berkaitan dengan sifat antioksidatifnya. Antioksidan alami seperti flavonoid yang banyak terdapat pada minuman dan buah anggur. Flavonoid merupakan senyawa fenol dan termasuk salah satumetabolit sekunder pada tumbuhan yang berfungsi sebagai antioksidan.

Antioksidan dapat menjadi strategi yang efektif untuk memperbaiki disfungsi endotel pada uremia dan target potensial untuk mengurangi risiko kardiovaskular pada populasi ini (Vera et al., 2018). Peradangan sel endotel dan biomarker yang bersirkulasi dari peradangan dan kapasitas antioksidan dikaitkan dengan kinerja latihan dan mikrosirkulasi otot betis yang iskemik selama latihan. Implikasi klinisnya adalah bahwa intervensi yang dirancang untuk mengurangi peradangan sel endotel dan biomarker inflamasi yang bersirkulasi, seperti terapi antioksidan, dapat meningkatkan kinerja olahraga pasien bergejala dengan penyakit arteri perifer (Gardner et al., 2015).

Berjalan lebih 2440 langkah setiap hari dan berjalan dengan irama lebih cepat dari 31,6 langkah/menit selama 30 menit setiap hari, keduanya terkait dengan kapasitas antioksidan sirkulasi yang lebih besar pada pasien simptomatik dengan PAD. Signifikansi klinisnya adalah bahwa program berjalan kaki di rumah dapat menjadi salah satu pendekatan untuk meningkatkan kapasitas antioksidan endogen (Gardner et al., 2017). Performa jalan kaki selaa enam menit pada pasien simptomatik dengan PAD dikaitkan dengan biomarker vaskular, 
karena jarak berjalan kaki dikaitkan secara negatif dengan pembengkakan sel endotelial dan secara positif terkait dengan kapasitas antioksidan yang bersirkulasi. Implikasi klinisnya adalah bahwa intervensi perilaku yang dirancang untuk mengurangi peradangan sel endotel dan meningkatkan kapasitas antioksidan yang bersirkulasi, seperti olahraga dan asupan antioksidan, dapat meningkatkan ambulasi pasien dengan PAD selama latihan submaksimal yang biasanya dilakukan selama aktivitas sehari-hari (Gardner et al., 2018).

\section{Perbedaan Komposisi Tubuh dan Total Antioksidan antara Intervensi Jalan Kaki dengan Jalan Kaki disertai Pemberian Jus Galoba}

Hasil penelitian terkait dengan pengaruh jalan kaki yang disertai dengan pemberian jus galoba terhadap perubahan komposisi tubuh dan nila total antioksidan disajikan pada tabel 3.

Tabel 3 telah menunjukkan bahwa, setelah dilakukan intervensi antara jalan kaki dibandingkan jalan kaki disertai pemberian jus, ternyata selisih komposisi tubuh 4,11 dan selisih total antioksidan hanya 0,02 . Selanjutnya hasil uji statistik diperoleh nilai $p=0,372$ sehingga dapat ditarik suatu keputusan ternyata tidak terdapat perbedaan komposisi tubuh antara intervensi jalan kaki dengan intervensi jalan kaki disertai pemberian jus galoba $(p>$ $0,05)$.

Mengenai komposisi lemak wanita usia $>55$ tahun tidak dipengaruhi oleh jalan kaki (Suryana \& Fitri, 2017), hal ini sejalan dengan penelitian (Hafid et al., 2019), pada remaja di SMA Karuna Dipa Palu menunjukkan hasil bahwa tidak ada hubungan antara latihan fisik termasuk jalan kaki dengan komposisi lemak tubuh. Komposisi lemak tubuh tidak mengalami penurunan dikarenakan juga karena ibu-ibu yang mengikuti latihan ini tidak secara rutin dan juga tidak bisa dikendalikan pola makan seharihari. Hal ini perkuat dengan penyataan Mabele et al. (2019), bahwa 59,2\% populasi wanita memiliki tingkat latihan fisik yang rendah.

Tabel 3. Perubahan komposisi lemak tubuh dan total antioksidan setelah dilakukan intervensi jalan kaki dan intervensi jalan kaki disertai pemberian jus galoba

\begin{tabular}{|c|c|c|c|c|c|}
\hline \multicolumn{2}{|c|}{ Kelompok Perlakuan } & Rerata \pm SD & $\Delta$ Rerata \pm SD & $\begin{array}{c}95 \% \text { CI } \\
\text { (Lower - Upper) }\end{array}$ & Nilai p \\
\hline Komposisi Lemak & Jalan Kaki & $38,1 \pm 3,732$ & $4,11 \pm 2,206$ & $5,24-8,74$ & 0,372 \\
\hline Tubuh & $\begin{array}{l}\text { Jalan Kaki + Jus } \\
\text { Galoba }\end{array}$ & $42,2 \pm 5,893$ & & & \\
\hline Total Antioksidan & $\begin{array}{l}\text { Jalan Kaki } \\
\text { Jalan Kaki + Jus } \\
\text { Galoba }\end{array}$ & $\begin{array}{l}1,58 \pm 0,145 \\
1,59 \pm 0,089\end{array}$ & $0,02 \pm 0,054$ & $0,11-0,13$ & 0,527 \\
\hline
\end{tabular}

Selanjutnya, hasil penelitian (tabel 3) juga diketahui bahwa secara statistik diperoleh nilai $\mathrm{p}=0,527$ terhadap perbedaan total antioksidan antara intervensi jalan kaki dengan intervensi jalan kaki disertai pemberian jus galoba. Hal ini menunjukkan bahwa tidak terdapat perbedaan nilai total antioksidan antara kedua jenis intervensi $(p>0,05)$.

Flafonoid berperan sebagai antioksidan dengan cara medonasikan atom hidrogennya atau melalui kemampuannya mengkelat logam, berada dalam bentuk glukosida (mengandung rantai samping glukosa) atau dalam bentuk bebas yang disebut aglikon (Zuraida et al., 2017). Berdasarkan hasil-hasil penelitian yang telah dilakukan, diyakini bahwa flavonoid sebagai salah satu kelompok senyawa fenolik yang memiliki sifat antioksidatif serta berperan dalam mencegah kerusakan sel dan komponen selularnya oleh radikal bebas reaktif (Redha, 2010).

Menurut Davies et al. (2019), mengatakan bahwa orang yang terbiasa aktif, waktu kurang duduk, akan mengalami kebugaran jantung dan pernapasan yang lebih tinggi dibanding dengan yang tidak aktif. Menurut Al Rahmad (2019), bahwa perilaku yang kurang baik ataupun kebiasaan dalam kehidupan seseorang yang tidak banyak melakukan aktifitas/gerakan fisik signifikan berdampak terhadap masalah gizi dan kesehatan seperti kegemukan bahkan obesitas. Hal ini sama dengan penelitian ini bahwa responden tidak melakukan latihan fisik jalan kaki secara rutin sehingga metabolisme tubuh tidak terjadi secara maksimal akibatnya 
komposisi lemah tubuh mereka tidak mengalami penurunan.

\section{Kesimpulan}

Tidak ada pengaruh latihan fisik jalan kaki terhadap komposisi lemak tubuh dan tidak ada pengaruh model latihan fisik jalan kaki dengan pemberian jus galoba terhadap kadar total Antioksidan.

Saran, untuk mendapatkan hasil yang efektif seharusnya jalan kaki dan minum jus galoba dilakukan secara rutin dengan pengontrolan pola makan dan waktu latihan fisik harus ditingkatkan menjadi 30 hari dan 30 menit setiap kali latihan serta penelitian selanjuntnya sampelnya harus lebih besar dan randomized controlled trial.

\section{Daftar Rujukan}

Al Rahmad, A. H. (2019). Keterkaitan asupan makanan dan sedentari dengan kejadian obesitas pada anak sekolah dasar di Kota Banda Aceh. Buletin Penelitian Kesehatan, 47(1), 67-76. https://doi.org/10.22435/bpk.v47i1.579

Bartlett, D. B., Willis, L. H., Slentz, C. A., Hoselton, A., Kelly, L., Huebner, J. L., Kraus, V. B., Moss, J., Muehlbauer, M. J., \& Spielmann, G. (2018). Ten weeks of high-intensity interval walk training is associated with reduced disease activity and improved innate immune function in older adults with rheumatoid arthritis: a pilot study. Arthritis Research \& Therapy, 20(1), 1-15. https://doi.org/https://doi.org/10.1186/ s13075-018-1624-x

Cebula, A., Tyka, A. K., Pilch, W., SzyguŁa, Z., PaŁka, T., Sztafa-CabaŁa, K., Fraczek, B., \& Tyka, A. (2017). Effects of 6-week nordic walking training on body composition and antioxidant status for women $>55$ years of age. International Journal of Occupational Medicine and Environmental Health, 30(3), 445-454.

https://doi.org/10.13075/ijomeh.1896.00 860

Davies, K. A., Bowden, V. S., Sprung, J. A., Norman, Thompson, A., Mitchell, K. L., Harrold, J. A., \& Finlayson, G. (2019). Physical activity and sedentary time: association with metabolic health and liver fat. Medicine \& Science in Sports \& Exercise, 51(6), 1169. https://doi.org/10.1249/mss.000000000 0001901

Gardner, A. W., Montgomery, P. S., Zhao, Y. D., Silva-Palacios, F., Ungvari, Z., Csiszar, A., \& Sonntag, W. E. (2017). Association between daily walking and antioxidant capacity in patients with symptomatic peripheral artery disease. Journal of Vascular Surgery, 65(6),

1762-1768. https://doi.org/10.1016/j.jvs.2016.12.108

Gardner, A. W., Montgomery, P. S., Zhao, Y. D., Ungvari, Z., Csiszar, A., \& Sonntag, W. E. (2018). Endothelial Cell Inflammation and Antioxidant Capacity are Associated With 6-Minute Walk Performance in Patients With Symptomatic Peripheral Artery Disease. Angiology, 69(5), 416-423. https://doi.org/10.1177/0003319717726 934

Gardner, A. W., Parker, D. E., Montgomery, P. S., Sosnowska, D., Casanegra, A. I., Ungvari, Z., Csiszar, A., \& Sonntag, W. E. (2015). Endothelial cell inflammation and antioxidant capacity are associated with exercise performance and microcirculation in patients with symptomatic peripheral artery disease. Angiology, 66(9), 867-874. https://doi.org/10.1177/0003319714566 863

Hafid, F., Cahyani, Y. E., \& Ansar, A. (2019). Aktivitas Fisik, Konsumsi Makanan cepat saji dan komposisi lemak tubuh remaja SMA Karuna Dipa Palu. PROMOTIF: Jurnal Kesehatan Masyarakat, 8(2), 104-111. https://doi.org/10.31934/promotif.v8i2.4 92

Junaidi, S. (2011). Pembinaan fisik lansia melalui aktivitas olahraga jalan kaki. Media Ilmu Keolahragaan Indonesia, 1(1), 17-21.

Karolkiewics, J., Michalak, E., Pospieszna, B., Deskur-Smielecka, E., Nowak, P., \& Pilaczyriska-Szczesniak, L. (2009). Response of oxidative stress markers and antioxidant parameters to an 8-week aerobic physical activity program in healthy, postmenopausal women. Archives of Gerontology and Geriatrics, 49(1), e67e71.

https://doi.org/https://doi.org/10.1016/j .archger.2008.09.001 
Kemenkes RI. (2017). Profil Kesehatan Indonesia Tahun 2016. Kementerian Kesehatan Republik Indonesia.

Mabele, G. K., Ekisawa, C. N., Delecluse, C., \& Bompeka, F. L. (2019). Level of physical activity and eating behavior: Risk factors associated with sedentariness among obese employees of a company in the city of Kinshasa province, Democratic Republic of Congo. Science and Sports, 34(3), 156-164. https://doi.org/10.1016/j.scispo.2018.11. 009

Murbawani, E. A. (2017). Hubungan Persen Lemak Tubuh dan Aktivitas Fisik dengan Tingkat Kesegaran Jasmani Remaja Putri. JNH (Journal of Nutrition and Health), 5(2), 69-84.

Nikolaidis, M., Paschalis, V., Giakas, G., Fatouros, I., Koutedakis, Y., Kouretas, D., \& Jamurtas, T. (2007). Decreased blood oxidative stress after repeated muscled damaging exercise. Medicine and Science in Sports and Exercise, 39(7), 1080-1089. https://doi.org/10.1249/mss.0b013e318 04ca10c

Polidori, M. C., Mecocci, P., Cherubini, A., \& Senin, U. (2000). Physical activity and oxidative stress during aging. International Journal of Sports Medicine, 21(3), 154-157. https://doi.org/10.1055/s-2000-8881

Redha, A. (2010). Flavonoid: Struktur, sifat antioksidatif dan peranannya dalam sistem biologis. Jurnal Belian, 9(2), 196-202. https://doi.org/10.1186/2110-5820-1-7

Rizka, M., \& Agus, A. (2018). Pengaruh latihan jalan kaki terhadap kebugaran jasmani lansia di Puskesmas Sungai Aur Kabupaten
Pasaman Barat. Jurnal Stamina, 1(1), 206218.

Salamena, F., Hiariej, A., \& Seumahu, C. A. (2018). Genetic characterization of Galoba Durian (Amonum spp.) in Ambon island based on Random Amplified Polymorphic DNA (RAPD). Agrotech Journal, 3(1), 27-33. https://doi.org/10.31327/atj.v3i1.524

Sudarsono, N. C. (2015). Indikator keberhasilan pengelolaan aktivitas fisik pada penyandang diabetes melitus tipe 2 . EJournal Kedokteran Indonesia, 3(1), 7076. https://doi.org/10.23886/ejki.3.4810.

Suryana, S., \& Fitri, Y. (2017). Hubungan aktivitas fisik dengan IMT dan komposisi lemak tubuh. AcTion: Aceh Nutrition Journal, 2(2), 114-119.

https://doi.org/http://dx.doi.org/10.3086 7/action.v2i2.64

Suryanto. (2010). Pentingnya olahraga bagi lansia. Medikora, 6(1), 23-30.

Vera, M., Torramade-Moix, S., Martin-Rodriguez, S., Cases, A., Cruzado, J. M., Rivera, J., Escolar, G., Palomo, M., \& Diaz-Ricart, M. (2018). Antioxidant and anti-inflammatory strategies based on the potentiation of glutathione peroxidase activity prevent endothelial dysfunction in chronic kidney disease. Cellular Physiology and Biochemistry, 51(3), 1287-1300. https://doi.org/10.1159/000495540

Zuraida, Z., Sulistiyani, S., Sajuthi, D., \& Suparto, I. H. (2017). Fenol, flavonoid, dan aktivitas antioksidan pada ekstrak kulit batang pulai (Alstonia scholaris R.Br). Jurnal Penelitian Hasil Hutan, 35(3), 211-219. 